\title{
Purification and Properties of Extracellular Glucosyltransferase Synthesizing 1,6-, 1,3- $\alpha$-D-Glucan from Streptococcus mutans Serotype a
}

\author{
By HIDEAKI TSUMORI, ATSUNARI SHIMAMURA AND \\ HIDEHIKO MUKASA* \\ Department of Chemistry, National Defense Medical College, 2 Namiki 3-chome, Tokorozawa, \\ Saitama 359, Japan
}

(Received 15 April 1985; revised 28 June 1985)

An extracellular glucosyltransferase (sucrose:1,6-, 1,3- $\alpha$-D-glucan 3- $\alpha$ - and 6- $\alpha$-D-glucosyltransferase, EC 2.4.1.-) of Streptococcus mutans HS6 (serotype a) was purified from culture supernatant by DEAE-Sepharose chromatography and preparative isoelectric focusing. The molecular weight measured by SDS-PAGE was 159000 and the isoelectric point was pH 4.9. The specific activity was 89.7 i.u. (mg protein) $)^{-1}$ and the optimum pH was 6.0 . The $K_{\mathrm{m}}$ value for sucrose was $4.9 \mathrm{~mm}$ and the enzyme activity was not stimulated by exogenous dextran T10. Glucan was synthesized de novo from sucrose by the purified enzyme and consisted of $49 \cdot 1 \mathrm{~mol} \%$ $1,6-\alpha$-linked glucose and $33.9 \mathrm{~mol} \% 1,3-\alpha$-linked glucose, with $13.6 \mathrm{~mol} \%$ terminal glucose and $3 \cdot 3 \mathrm{~mol} \% 1,3,6-\alpha$-branched glucose.

\section{INTRODUCTION}

Serotype $a, d$ and $g$ strains of the cariogenic micro-organism Streptococcus mutans secrete three kinds of glucosyltransferase; strains of serotypes $c, e$ and $f$ secrete basic glucosyltransferases and acidic fructosyltransferases (Carlsson, 1970; Ciardi et al., 1976; Shimamura et al., 1982; Mukasa et al., $1982 b$; Tsumori et al., 1983b). Serotype $b$ strains also produce both glucosyland fructosyltransferases (Scales et al., 1975; Tsumori et al., 1983b). These enzymes exist as high molecular weight complexes (400000 to 2000000$)$ and synthesize adhesive water-insoluble polysaccharide from sucrose by a cooperative action (Mukasa \& Slade, 1974b; Ciardi et al., 1977; Mukasa et al., 1979). Highly-branched 1,6- $\alpha$-D-glucan synthases have been purified from serotype $a, c$ and $g$ strains in our laboratory (Shimamura et al., 1982; Mukasa et al., 1982b; Tsumori et al., 1983a); in addition, 1,3- $\alpha$-D-glucan synthases have been purified from serotype $a$, $d$ and $g$ strains (Fukushima et al., 1981; Fukui et al., 1982; Koga et al., 1983; Tsumori et al., 1985). However, the third glucosyltransferase has yet to be isolated, purified and characterized from serotype $a, d$ and $g$ strains: hence the mechanism of synthesis of the adhesive insoluble glucan is not yet known. A glucosyltransferase has been partially purified from strain OMZ176 (serotype $d$ ) (Koga et al., 1983) which might correspond to the third enzyme, although its properties were not adequately characterized. It seemed essential, therefore, to purify and characterize the third glucosyltransferase in order to establish the mechanisms of adhesive insoluble glucan synthesis by the three kinds of glucosyltransferases and so advance studies in the prevention of dental caries. In this study, we have purified this glucosyltransferase from $S$. mutans HS6 (serotype $a$ ) and shown it to be a bifunctional enzyme which synthesizes watersoluble 1,6-, 1,3- $\alpha$-D-glucan.

\section{METHODS}

Organism and culture conditions. S. mutans HS6 (serotype $a$ ) was used throughout the present study (Tsumori et al., 1983a). The batch culture method used was that reported previously (Tsumori et al., 1985). The OD 550 of the culture at harvest was $6 \cdot 1$ and the cell-free culture supernatant was obtained by centrifugation for $30 \mathrm{~min}$ at $8900 \mathrm{~g}$.

Purification of 1,6-, 1,3- $\alpha$-D-glucan synthase. All steps were done at 0 to $5^{\circ} \mathrm{C}$ unless otherwise indicated. 
(1) Ultrafiltration. The culture supernatant (51) was concentrated to $130 \mathrm{ml}$ and equilibrated with $30 \mathrm{mM}-\mathrm{NaCl}$ in $10 \mathrm{mM}$-Tris/ $\mathrm{HCl}$ buffer ( $\mathrm{pH} \mathrm{7.4)}$ as reported by Tsumori et al. (1985).

(2) DEAE-Sepharose chromatography. The concentrated enzyme solution was applied to a DEAE-Sepharose column $(1.8 \times 35 \mathrm{~cm})$ previously equilibrated with $30 \mathrm{mM}-\mathrm{NaCl}$ in $10 \mathrm{mM}$-Tris/ $\mathrm{HCl}$ buffer $(\mathrm{pH} 7.4)$. The column was washed with $100 \mathrm{ml}$ of the same buffer containing $30 \mathrm{~mm}-\mathrm{NaCl}$. The enzyme was then eluted with $300 \mathrm{ml}$ $90 \mathrm{mM}-\mathrm{NaCl}$ in the buffer at a flow rate of $48 \mathrm{ml} \mathrm{h}^{-1}$ (Tsumori et al., 1985). The eluate was concentrated to $24 \mathrm{ml}$ and the buffer was changed to 5 mM-sodium phosphate (pH 6.5) by ultrafiltration (Mukasa et al., $1982 \mathrm{~b}$ ).

(3) Preparative isoelectric focusing. This was done using a $110 \mathrm{ml}$ LKB Ampholine electrofocusing column. The density gradient was formed manually (Vesterberg, 1971) with glycerol, and Ampholine pH 4-6, Ampholine pH 3.5-10 and Triton X-100 were used at concentrations of $0.98,0.02$ and $0.5 \%$, respectively. The enzyme ( $24 \mathrm{ml})$ was focused at $800 \mathrm{~V}$ for $8 \mathrm{~h}, 1300 \mathrm{~V}$ for $2 \mathrm{~h}, 1500 \mathrm{~V}$ for $2 \mathrm{~h}$ and $1950 \mathrm{~V}$ for $12 \mathrm{~h}$. Samples $(1 \mathrm{ml})$ were sucked out and tested for activity, and active fractions were pooled.

The second preparative isoelectric focusing was done as described above except that $0.95 \%$ Ampholine pH 5-7, $0.05 \%$ Ampholine $\mathrm{pH} \mathrm{3.5-5}$ and 2\% Triton X-100 were used, and the volume of the enzyme solution was $3 \mathrm{ml}$.

Enzyme assay. Enzyme activity was routinely measured by the method of Mukasa et al. (1979) with the following modifications. The reaction mixture in a final volume of $1.75 \mathrm{ml}$ contained $0.1 \mathrm{M}$-sodium phosphate buffer (pH 6.5), $41.7 \mathrm{~mm}$-sucrose, $0.01 \%$ Merthiolate and 0.5 to $50 \mu$ l enzyme solution with or without $0.6 \mathrm{mg}$ dextran T10. The reaction was done at $37^{\circ} \mathrm{C}$ for 2 to $6 \mathrm{~h}$ and terminated by heating at $100^{\circ} \mathrm{C}$ for $5 \mathrm{~min}$. After insoluble materials had been removed, the reducing sugar released was measured by the method of Somogyi (1945), using glucose as a standard. One unit of activity (i.u.) was the amount of enzyme releasing $1 \mu$ mol reducing sugar from sucrose per $\min$ at $37^{\circ} \mathrm{C}$.

Soluble glucan was collected as a $75 \%(\mathrm{v} / \mathrm{v})$ ethanol precipitate and measured by the phenol/sulphuric acid method (Dubois et al., 1956), using glucose as a standard. One unit (i.u.) of 1,6-, 1,3- $\alpha$-D-glucan synthase activity was defined as the amount of enzyme catalysing the incorporation into glucan from sucrose of $1 \mu \mathrm{mol}$ glucose $\min ^{-1}$ at $37^{\circ} \mathrm{C}$.

Analytical isoelectric focusing. This was done as reported by Mukasa et al. (1982a) except that the gel contained $0 \cdot 1 \%$ Triton X-100. After focusing, protein was stained with Coomassie brilliant blue R-250 (Vesterberg et al.,

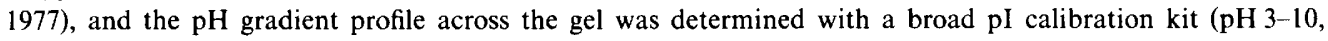
Pharmacia). 1,6-, 1,3- $\alpha$-D-Glucan synthase activity was detected by staining the gel with periodic acid-Schiff reagent after incubation of the focused gel for $15 \mathrm{~h}$ at $37^{\circ} \mathrm{C}$ in $0.1 \mathrm{M}$-sodium phosphate buffer $(\mathrm{pH} 6.5)$ containing $3 \%(\mathrm{w} / \mathrm{v})$ sucrose and $0.01 \%$ Merthiolate (Mukasa et al., 1982a). After $2 \mathrm{~h}$ incubation of the gel in the same reaction mixture, reducing sugar released was detected with 2,3,5-triphenyltetrazolium chloride (Gabriel \& Wang, 1969).

$S D S-P A G E$. The enzyme solution ( $4 \mu \mathrm{g}$ protein) was subjected to SDS-PAGE according to Weber \& Osborn (1969) using $5 \%(\mathrm{w} / \mathrm{v})$ gel at $5 \mathrm{~mA}$ per tube constant current for $6.5 \mathrm{~h}$. Gels were stained for protein with Coomassie brilliant blue R-250 and calibrated with Bio-Rad high molecular weight protein standards. The activity was detected with periodic acid-Schiff reagent after incubation of the gel in $0.1 \mathrm{M}$-sodium phosphate buffer (pH 6.5) containing 3\%(w/v) sucrose and $1 \%$ Triton X-100 (Russell, 1979) and $0.01 \%$ Merthiolate.

Antisera and serological procedure. Antisera against 1,6-, 1,3- $\alpha$-D-glucan synthase and 1,3- $\alpha$-D-glucan synthase were produced in New Zealand White rabbits as previously reported (Tsumori et al., 1985). An antiserum against highly-branched 1,6- $\alpha$-D-glucan synthase was prepared according to Mukasa \& Slade (1973a). Double immunodiffusion tests were done according to Ouchterlony (1958) except that $0.3 \%$ agarose was used.

Determination of $\mathrm{pH}$ optimum and $K_{\mathrm{m}}$. The $\mathrm{pH}$ optimum was estimated by measuring the enzyme activity in $0 \cdot 1 \mathrm{M}$-sodium acetate ( $\mathrm{pH} 4 \cdot 0$ to $5 \cdot 5$ ), $0 \cdot 1 \mathrm{M}$-sodium maleate ( $\mathrm{pH} 5 \cdot 0$ to $7 \cdot 0$ ) and $0 \cdot 1 \mathrm{M}$-sodium phosphate (pH 6.0 to $7 \cdot 5)$.

The $K_{\mathrm{m}}$ for sucrose was estimated by measuring the activity in $0 \cdot 1 \mathrm{M}$-sodium maleate buffer ( $\mathrm{pH} 6 \cdot 0$ ) containing 1 to $100 \mathrm{~mm}$-sucrose at $37^{\circ} \mathrm{C}$ for $90 \mathrm{~min}$ according to the method of Eisenthal \& Cornish-Bowden (1974).

Linkage analysis of glucan. Glucan was synthesized by the purified enzyme ( $10 \mu \mathrm{g}$ protein) in $10 \mathrm{ml} 0 \cdot 1 \mathrm{M}$-sodium maleate buffer (pH 6.0) containing $5 \%(\mathrm{w} / \mathrm{v})$ sucrose and $0.01 \%$ Merthiolate for $71 \mathrm{~h}$; it was collected as a $75 \%$ (v/v) ethanol precipitate and washed three times. The glucan (1 to $12 \mathrm{mg}$ ) was permethylated (Hakomori, 1964), hydrolysed, reduced and acetylated. The partially methylated glucitol acetate was analysed on a gas-liquid chromatograph (GC-6A, Shimadzu, Kyoto, Japan) on a WCOT column of Silicone OV $101(20 \mathrm{~m} \times 0 \cdot 25 \mathrm{~mm})$. The separated derivatives were identified by an auto GC-MS 6020 (Shimadzu; Shimamura et al., 1982).

Other assays. Protein and carbohydrate contents were determined with a densitometer (Chromatoscanner CS910, Shimadzu) as previously reported (Tsumori et al., 1985). Protein content was also determined by the Lowry method with bovine serum albumin as a standard.

Fructan was analysed as described above, except that the permethylated fructan was hydrolysed according to Ebisu et al. (1975).

Materials. DEAE-Sepharose and $\mathrm{pI}$ markers were purchased from Pharmacia. Molecular weight markers and Ampholines were obtained from Bio-Rad and LKB, respectively. All other chemicals were of analytical or reagent grade. 


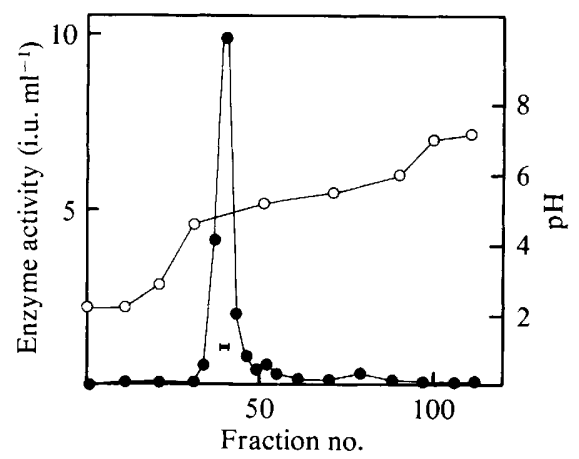

Fig. 1. Second preparative isoelectric focusing of the DEAE-Sepharose fraction from $S$. mutans HS6 (serotype $a$ ). 0 , Enzyme activity, estimated by measuring the rate of reducing sugar-release from sucrose; $\bigcirc, \mathrm{pH}$. The horizontal bar indicates the fractions pooled.

Table 1. Purification of 1,6-, 1,3- $\alpha$-D-glucan synthase from S. mutans HS6 (serotype a)

\begin{tabular}{|c|c|c|c|c|c|}
\hline Step & $\begin{array}{l}\text { Total protein } \\
\text { (mg) }\end{array}$ & $\begin{array}{l}\text { Activity* } \\
\text { (i.u.) }\end{array}$ & $\begin{array}{l}\text { Specific activity } \\
\text { (i.u. } \mathrm{mg}^{-1} \text { ) }\end{array}$ & $\begin{array}{c}\text { Recovery } \\
(\%)\end{array}$ & $\begin{array}{l}\text { Purification } \\
\quad \text { (fold) }\end{array}$ \\
\hline 1. Ultrafiltration & $556 \cdot 4$ & 2069 & $3 \cdot 72$ & 100 & 1 \\
\hline 2. DEAE-Sepharose & 20.8 & 662 & $31 \cdot 8$ & 32 & $8 \cdot 5$ \\
\hline 3. Preparative IEF $\dagger$ & & & & & \\
\hline 1 st & $2 \cdot 4$ & 205 & $85 \cdot 4$ & 9.9 & $23 \cdot 0$ \\
\hline 2nd & $1 \cdot 0$ & $89 \cdot 7$ & $89 \cdot 7$ & $4 \cdot 3$ & $24 \cdot 1$ \\
\hline
\end{tabular}

\section{RESULTS}

\section{Purification of 1,6-, 1,3- $\alpha$-D-glucan synthase}

1,6-, 1,3- $\alpha$-D-Glucan synthase of $S$. mutans HS6 (serotype $a$ ) was purified from the culture supernatant by DEAE-Sepharose chromatography and preparative isoelectric focusing as summarized in Table 1. 1,6-, 1,3- $\alpha$-D-Glucan synthase was eluted from the DEAE-Sepharose column with $90 \mathrm{~mm}-\mathrm{NaCl}$ in $10 \mathrm{~mm}$-Tris/HCl buffer $(\mathrm{pH} 7.4)$, whereas other enzymes such as $1,3-\alpha$-D-glucan synthase and highly-branched 1,6- $\alpha$-D-glucan synthase were not eluted under the same conditions (Tsumori et al., 1985). The enzyme was further purified by two steps of preparative isoelectric focusing, and fractionated as a single active peak (Fig. 1). Fructosyltransferase and dextranase activities were not detected. The carbohydrate content of the purified enzyme was $1.5 \%$.

\section{Properties of 1,6-, 1,3- $\alpha$-D-glucan synthase}

Electrophoretic properties. The purified enzyme moved as a single band of protein and activity in SDS-PAGE and analytical isoelectric focusing (Fig. 2). The enzyme activity stained with periodic acid-Schiff reagent coincided in position with the release of reducing sugar stained with 2,3,5-triphenyltetrazolium chloride. The enzyme had an isoelectric point of $\mathbf{4 . 9}$ and a molecular weight of 159000 (Fig. 2).

Immunological analysis. 1,6-, 1,3- $\alpha$-D-Glucan synthase, highly-branched 1,6- $\alpha$-D-glucan synthase and 1,3- $\alpha$-D-glucan synthase purified from strain HS6 (serotype $a$ ) formed precipitin lines against the corresponding antisera, but these enzymes were immunologically unrelated to each other (Fig. 3a). The 1,6-, 1,3- $\alpha$-D-glucan synthase of strain HS6 was partially identical with the corresponding enzyme purified from strain 6715 (serotype $g$ ) and with the enzyme in the crude enzyme preparation of strain B13 (serotype $d$ ) (Fig. $3 b$ ).

Kinetic studies. The $\mathrm{pH}$ optimum was 6.0 , and the $K_{\mathrm{m}}$ value for sucrose was $4.9 \pm 1.7$ (SE) mM at $\mathrm{pH} 6.0$. The enzyme activity was not stimulated by exogenous dextran $\mathrm{T} 10$ in the range 0.01 to $2 \cdot 0 \mathrm{mg} \mathrm{ml}^{-1}$. 

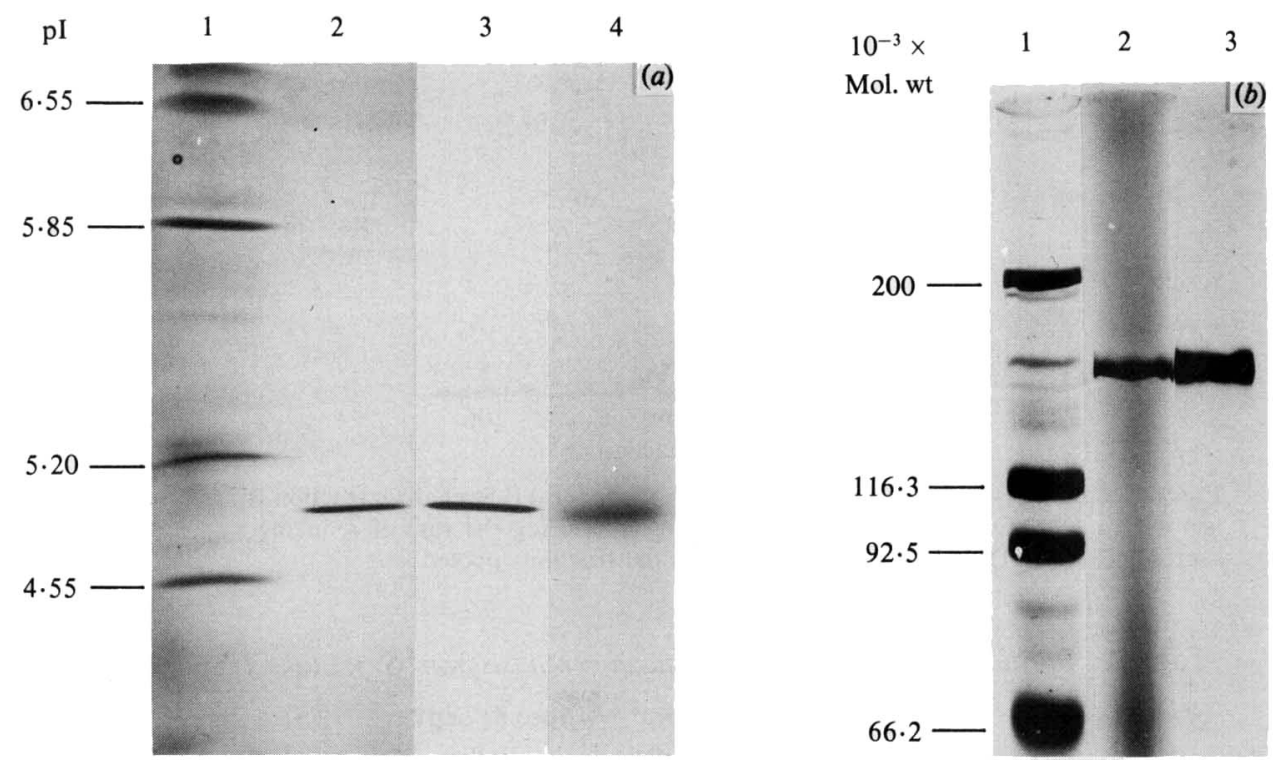

Fig. 2. Electrophoretic analyses of the purified glucosyltransferase from $S$. mutans HS6 (serotype $a$ ). (a) Analytical isoelectric focusing. The pI markers ( 1 to $2.5 \mu \mathrm{g}$ protein; lane 1$)$ and the purified enzyme $(0.4 \mu \mathrm{g}$ protein; lane 2$)$ were stained with Coomassie brilliant blue $\mathrm{R}-250$; the enzyme activity was stained with periodic acid-Schiff reagent (lane 3) and 2,3,5-triphenyltetrazolium chloride (lane 4) after the incubation of the gel in $3 \%(\mathrm{w} / \mathrm{v})$ sucrose solution. (b) SDS-PAGE. The molecular weight markers ( $1 \mu \mathrm{g}$ protein; lane 1$)$ and the purified enzyme $(4 \mu \mathrm{g}$ protein; lane 2$)$ were stained with Coomassie brilliant blue R-250; the enzyme activity was stained with periodic acid-Schiff reagent (lane 3 ).
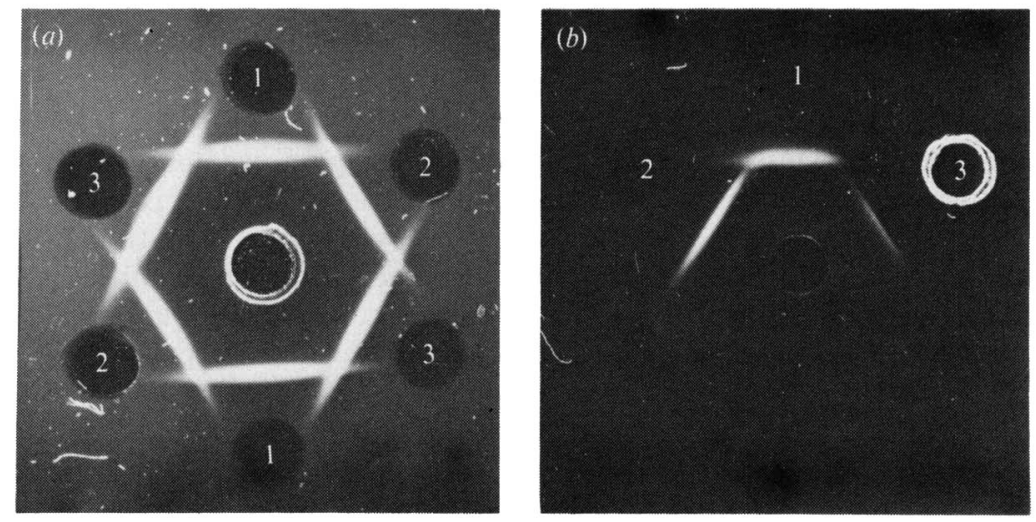

Fig. 3. (a) Immunodiffusion of three kinds of glucosyltransferase against a mixture of the antisera to the corresponding enzymes (1,6-, 1,3- $\alpha$-D-glucan synthase/highly-branched 1,6- $\alpha$-D-glucan synthase/1,3- $\alpha$ D-glucan synthase, 1-4:1:3·3, by vol.; centre well, $20 \mu \mathrm{l})$. 1, 1,6-, 1,3- $\alpha$-D-glucan synthase $(4 \mu \mathrm{g}) ; 2,1,3-\alpha-$ D-glucan synthase $(0 \cdot 2 \mu \mathrm{g}) ; 3$, highly-branched 1,6- $\alpha$-D-glucan synthase $(6 \mu \mathrm{g})$. (b) Immunodiffusion of enzyme preparations obtained from different serotypes against antiserum to 1,6-, 1,3- $\alpha$-D-glucan synthase (centre well, $8 \mu \mathrm{l})$. 1, 1,6-, 1,3- $\alpha$-D-glucan synthase from strain HS6 (serotype $a)(2 \mu \mathrm{g}) ; 2,1,6-$, $1,3-\alpha$-D-glucan synthase from strain 6715 (serotype $g$ ) $(1 \cdot 4 \mu \mathrm{g}) ; 3$, crude enzyme preparation from strain B13 (serotype $d$ ) $(330 \mu \mathrm{g})$.

Product analysis. The reaction mixture became viscous and somewhat opalescent during glucan synthesis and the synthesized product would not redissolve in water after precipitation with $75 \%(\mathrm{v} / \mathrm{v})$ ethanol.

Linkage analysis of the glucan gave the acetate derivatives of 2,3,4,6-tetra-, 2,3,4-tri-, 2,4,6tri- and 2,4-di-O-methyl-D-glucitol in the molar ratio $1 \cdot 0: 3 \cdot 6: 2 \cdot 5: 0 \cdot 2$. This indicated that the 
Table 2. Characteristics of the three kinds of glucosyltransferase purified from S. mutans HS6 (serotype a)

\begin{tabular}{|c|c|c|c|c|c|c|c|c|c|c|}
\hline \multirow[b]{2}{*}{$\begin{array}{l}\text { D-Glucan } \\
\text { synthase* }\end{array}$} & & \multirow[b]{2}{*}{$\begin{array}{l}10^{-3} \times \\
\text { Mol. wt }\end{array}$} & \multirow[b]{2}{*}{$\mathrm{pI}$} & \multirow[b]{2}{*}{$\begin{array}{c}K_{\mathrm{mm}} \\
(\mathrm{mM})\end{array}$} & \multirow[b]{2}{*}{$\underset{\text { optimum }}{\mathrm{pH}}$} & \multicolumn{4}{|c|}{$\begin{array}{c}\text { Structure of glucan } \\
\alpha \text {-linked glucose }(\mathrm{mol} \%)\end{array}$} & \multirow{2}{*}{$\begin{array}{l}\text { Primer } \\
\text { depen- } \\
\text { dency }\end{array}$} \\
\hline & & & & & & $\overparen{\text { Terminal }}$ & $1,6-$ & $1,3-$ & $1,3,6-$ & \\
\hline $1,6-, 1,3-\alpha^{-a}$ & & 159 & 4.9 & 4.9 & $6 \cdot 0$ & $13 \cdot 6$ & $49 \cdot 1$ & 33.9 & $3 \cdot 3$ & No \\
\hline $1,3-\alpha^{-b}$ & & 158 & $5 \cdot 2$ & $1 \cdot 2$ & 6.0 & $0 \cdot 2$ & 0.6 & $99 \cdot 2$ & trace & Yes \\
\hline Highly & I & 161 & $4 \cdot 5$ & 1.3 & 5.5 & $18 \cdot 6$ & $64 \cdot 7$ & 0 & $16 \cdot 7$ & Yes \\
\hline $1,6-\alpha^{-c}$ & II & 174 & $4 \cdot 2$ & & & $24 \cdot 5$ & 55.8 & 0 & $19 \cdot 7$ & \\
\hline
\end{tabular}

* References: $a$, this paper; $b$, Tsumori et al. (1985); $c$, Tsumori et al. (1983a).

glucan was composed of 1,6- and 1,3- $\alpha$-linked glucose with some 1,3,6- $\alpha$-branch points and was essentially different in structure from highly-branched 1,6- $\alpha$-D-glucan, 1,3- $\alpha$-D-glucan and dextran T10 (1,6- $\alpha$-D-glucan).

\section{DISCUSSION}

1,6-, 1,3- $\alpha$-D-Glucan synthase was purified from the culture supernatant of $S$. mutans HS6 (serotype $a$ ) by DEAE-Sepharose chromatography and preparative isoelectric focusing. Although the enzyme had previously been expected to be 1,6- $\alpha$-D-glucan synthase (Shimamura et al., 1983; Tsumori et al., $1983 \mathrm{~b}$ ), the purified enzyme synthesized a soluble glucan consisting of $1,6-\alpha$-linked glucose $(49.1 \mathrm{~mol} \%)$ with a high quantity of $1,3-\alpha$-linked glucose $(33.9 \mathrm{~mol} \%)$. Therefore, the final enzyme preparation obtained in this study was suspected of containing a significant amount of 1,3- $\alpha$-D-glucan synthase, and an attempt to separate the supposed 1,3- $\alpha$-Dglucan synthase from this preparation was done by SDS-PAGE with a 50 -cm-long polyacrylamide gel (data not shown). After the enzyme or enzymes had migrated about $45 \mathrm{~cm}$, the gel was cut into $2 \mathrm{~mm}$ slices, extracted, and the extracts used to synthesize glucans from sucrose. The linkage analyses showed that the structures of the glucans formed were similar to that of the glucan synthesized by the purified enzyme (data not shown), indicating that the 1,3and the 1,6- $\alpha$-bond-forming activities of the final enzyme preparation were inseparable electrophoretically.

The three kinds of glucosyltransferase purified from strain HS6 were immunologically unrelated to each other (Fig. $3 a$ ). Considering this observation, the enzyme purified in the present study is most probably a bifunctional enzyme with 1,6- and 1,3- $\alpha$-bond-forming activities (sucrose:1,6-, 1,3- $\alpha$-D-glucan 3- $\alpha$ - and 6- $\alpha$-D-glucosyltransferase).

Côté \& Robyt (1982) have purified an alternansucrase from Leuconostoc mesenteroides NRRL B-1 355 culture supernatant which synthesized an alternating 1,6-, 1,3- $\alpha$-D-glucan. The alternan dissolved readily in water and was not hydrolysed by dextranase or 1,3- $\alpha$-glucanase. In contrast, the glucan synthesized in the present study failed to redissolve in water after precipitation by ethanol $(75 \%, \mathrm{v} / \mathrm{v})$ and was hydrolysed up to $70 \%$ by dextranase (data not shown). These data indicated that the enzyme purified from strain HS6 was distinct from the alternansucrase of $L$. mesenteroides.

The HS6-enzyme was not stimulated by exogenous dextran T10 and the glucan synthesized was composed of 1,6- and 1,3- $\alpha$-linked glucose. These observations are compatible with the known properties of the third glucosyltransferase from strain 6715 (serotype $g$ ) described by Shimamura et al. (1983), and those of the partially purified glucosyltransferase from strain OMZ176 (serotype $d$ ) which synthesized soluble glucan (Koga et al., 1983). Although the purified enzyme from strain HS6 (serotype $a$ ) showed partial immunological identity with the corresponding enzymes from strains B13 (serotype $d$ ) and 6715 (serotype $g$ ) (Fig. $3 b$ ), its physical characteristics such as molecular weight and isoelectric point were significantly different from those reported by Shimamura et al. (1983) and Koga et al. (1983). 
The highly branched 1,6- $\alpha$-D-glucan synthase and 1,3- $\alpha$-D-glucan synthase from strain HS6 are partially identical immunologically to the corresponding enzymes from serotypes $d$ and $g$ previously reported by Fukui et al. $(1974 ; 1983)$ and Tsumori et al. $(1983 a ; 1985)$. The $1,6-, 1,3-\alpha-$ D-glucan synthases from serotype $a, d$ and $g$ strains were also partially identical with each other (Fig. $3 b$ ). These observations are compatible with the partial identity among cell wall polysaccharide antigens purified from $S$. mutans serotype $a$ and $d(g)$ strains (Mukasa $\&$ Slade, $1973 a$; Linzer \& Slade, 1974). On the other hand, the three kinds of glucosyltransferase secreted from one strain are immunologically unrelated (Fig. $3 a$; Shimamura et al., 1983). Properties of the three enzymes purified from $S$. mutans HS6 (serotype $a$ ) are summarized in Table 2. It would be interesting to know the amino acid sequences in order to clarify the differences among these enzymes.

Highly-branched 1,6- $\alpha$-D-glucan synthase and 1,3- $\alpha$-D-glucan synthase are stimulated by exogenous dextran T10 (Shimamura et al., 1982; Fukui et al., 1982), whereas 1,6-, 1,3- $\alpha$-D-glucan synthase synthesized glucan regardless of the presence of dextran T10. Therefore, 1,6-, 1,3- $\alpha$-Dglucan synthase may initially synthesize the soluble glucan which would successively stimulate the other two glucosyltransferase activities, resulting in the formation of adhesive insoluble glucan by the cooperative action of the three kinds of glucosyltransferases (Mukasa \& Slade, 1974b; Ciardi et al., 1977; Mukasa et al., 1979), and in the adherence of $S$. mutans cells to smooth surfaces (Gibbons \& Nygaard, 1968; Mukasa \& Slade, 1973b, 1974a).

\section{REFERENCES}

Carlsson, J. (1970). A levansucrase from Streptococcus mutans. Caries Research 4, 97-113.

Ciardi, J. E., Hageage, G. J., Jr \& Wittenberger, C. L. (1976). Multicomponent nature of the glucosyltransferase system of Streptococcus mutans. Journal of Dental Research 55 (Special Issue C), C87-C96.

Ciardi, J. E., Beaman, A. J. \& Wittenberger, C. L. (1977). Purification, resolution, and interaction of the glucosyltransferases of Streptococcus mutans 6715. Infection and Immunity 18, 237-246.

Côté, G. L. \& RoBYT, J. F. (1982). Isolation and partial characterization of an extracellular glucansucrase from Leuconostoc mesenteroides NRRL B-1355 that synthesizes an alternating $(1 \rightarrow 6),(1 \rightarrow 3)-\alpha$-D-glucan. Carbohydrate Research 101, 57-74.

Dubois, M. L., Gilles, K. A., Hamilton, J. K., Rebers, P. A. \& SMITH, F. (1956). Colorimetric method for determination of sugars and related substances. Analytical Chemistry 28, 350-356.

Ebisu, S., Kato, K., Kotani, S. \& Misaki, A. (1975). Structural differences in fructans elaborated by Streptococcus mutans and Strep. salivarius. Journal of Biochemistry 78, 879-887.

Eisenthal, R. \& CoRnish-Bowden, A. (1974). The direct linear plot. A new graphical procedure for estimating enzyme kinetic parameters. Biochemical Journal 139, 715-720

Fukui, K., Fukui, Y. \& Moriyama, T. (1974). Some immunochemical properties of dextransucrase and invertase from Streptococcus mutans. Infection and Immunity 10, 985-990.

Fukui, K., Moriyama, T., Miyake, Y., Mizutani, K. \& TANAKA, O. (1982). Purification and properties of glucosyltransferase responsible for water-insoluble glucan synthesis from Streptococcus mutans. Infection and Immunity 37, 1-9.

Fukui, K., Kokeguchi, S., Kato, K., Miyake, Y., Nogami, R. \& Moriyama, T. (1983). Immunochemical properties of glucosyltransferases from Streptococcus mutans. Infection and Immunity 39, 762-766.
Fukushima, K., Motoda, R., Takada, K. \& Ikeda, T. (1981). Resolution of Streptococcus mutans glucosyltransferases into two components essential to waterinsoluble glucan synthesis. FEBS Letters 128, $213-$ 216.

GabRiel, O. \& WANG, S.-F. (1969). Determination of enzymatic activity in polyacrylamide gels. I. Enzymes catalyzing the conversion of nonreducing substrates to reducing products. Analytical Biochemistry 27, 545-554.

Gibbons, R. J. \& NygaARd, M. (1968). Synthesis of insoluble dextran and its significance in the formation of gelatinous deposits by plaque-forming streptococci. Archives of Oral Biology 13, 1249-1262.

HAKOMORI, S. (1964). A rapid permethylation of glycolipid, and polysaccharide catalyzed by methylsulfinyl carbanion in dimethyl sulfoxide. Journal of Biochemistry 55, 205-208.

Koga, T., SATo, S., YakushiJ, T. \& INOUE, M. (1983). Separation of insoluble and soluble glucan-synthesizing glucosyltransferases of Streptococcus mutans OMZ176 (serotype d). FEMS Microbiology Letters 16, $127-130$

Linzer, M. \& Slade, H. D. (1974). Purification and characterization of Streptococcus mutans group $d$ cell wall polysaccharide antigen. Infection and Immunity 10, 361-368.

MukaSA, H. \& Slade, H. D. (1973a). Extraction, purification, and chemical and immunological properties of the Streptococcus mutans group " $a$ " polysaccharide cell wall antigen. Infection and Immunity 8 , 190-198.

Mukasa, H. \& Slade, H. D. (1973b). Mechanism of adherence of Streptococcus mutans to smooth surfaces. I. Roles of insoluble dextran-levan synthetase enzymes and cell wall polysaccharide antigen in plaque formation. Infection and Immunity 8, 555-562.

Mukasa, H. \& Slade, H. D. (1974a). Mechanism of adherence of Streptococcus mutans to smooth surfaces. II. Nature of the binding site and the 
adsorption of dextran-levan synthetase enzymes on the cell-wall surface of the Streptococcus. Infection and Immunity 9, 419-429.

Mukasa, H. \& Slade, H. D. (1974b). Mechanism of the adherence of Streptococcus mutans to smooth surfaces. III. Purification and properties of the enzyme complex responsible for adherence. Infection and Immunity 10, 1135-1145.

Mukasa, H., Shimamura, A. \& Tsumori, H. (1979). Effect of salts on water-insoluble glucan formation by glucosyltransferase of Streptococcus mutans. Infection and Immunity 23, 564-570.

Mukasa, H., Shimamura, A. \& Tsumori, H. (1982a). Direct activity stains for glycosidase and glucosyltransferase after isoelectric focusing in horizontal polyacrylamide gel layers. Analytical Biochemistry 123, 276-284.

Mukasa, H., Shimamura, A. \& Tsumori, H. (1982 $b$ ). Purification and characterization of basic glucosyltransferase from Streptococcus mutans serotype $c$. Biochimica et biophysica acta 719, 81-89.

OUCHTERLONY, O. (1958). Diffusion in gel methods for immunological analysis. Progress in Allergy 5, 1-9.

Russell, R. R. B. (1979). Use of Triton X-100 to overcome the inhibition of fructosyltransferase by SDS. Analytical Biochemistry 97, 173-175.

SCales, W. R., Long, L. W. \& Edwards, J. R. (1975). Purification and characterization of a glycosyltransferase complex from the culture broth of Streptococcus mutans FA 1. Carbohydrate Research 42, 325338

Shimamura, A., Tsumori, H. \& Mukasa, H. (1982). Purification and properties of Streptococcus mutans extracellular glucosyltransferase. Biochimica et biophysica acta 702, 72-80.

Shimamura, A., Tsumori, H. \& Mukasa, H. (1983). Three kinds of extracellular glucosyltransferases from Streptococcus mutans 6715 (serotype g). FEBS Letters 157, 79-84.

Somogyi, M. (1945). A new reagent for the determination of sugars. Journal of Biological Chemistry 160 , 61-68.

Tsumori, H., Shimamura, A. \& Mukasa, H. (1983a). Purification and properties of extracellular glucosyltransferases from Streptococcus mutans serotype a Journal of General Microbiology 129, 3251-3259.

TSumori, H., Shimamura, A. \& MUKaSA, H. (1983b). Comparative study of Streptococcus mutans extracellular glycosyltransferases by isoelectric focusing. Journal of General Microbiology 129, 3261-3269.

Tsumori, H., Shimamura, A. \& Mukasa, H. (1985). Purification and properties of extracellular glucosyltransferase synthesizing 1,3- $\alpha$-D-glucan from Streptococcus mutans serotype a. Journal of General Microbiology 131, 553-559.

VeSTERBERG, O. (1971). Isoelectric focusing of proteins. Methods in Enzymology 22, 389-412.

Vesterberg, O., Hansén, L. \& Suösten, A. (1977). Staining of proteins after isoelectric focusing in gels by new procedures. Biochimica et biophysica acta 491 , 160-166.

WEBER, K. \& OSBORN, M. (1969). The reliability of molecular weight determinations by dodecyl sulfatepolyacrylamide gel electrophoresis. Journal of Biological Chemistry 244, 4406-4412. 